\title{
Developing Kindergarten Curricula According to Egypt's 2030 Vision
}

\author{
Dr. Rasmiya Mohamed Farghali \\ Faculty of Early Childhood Education, \\ Fayoum University, Egypt \\ drrasmiya.matwatwaly@gmail.com
}

\begin{abstract}
Egypt Education Vision 2030 Outlines a Long-Term Strategy to Establish Curricula for Education at all Stages. This Study Focuses on The Curricula of Kindergarten Stage. Puppet Theaters It is considered one of the influential curricula in the kindergarten stage, so this Study aims to design a proposed unit for the puppet theater curriculum according to Egypt's 2030 vision. the main goal of the proposed unit is to achieve the values of citizenship and belonging to kindergarten children. The research sample consisted of) 50(pupils in kindergarten in Fayoum Governorate; Results show differences with statistical differences at level of $\leqslant 0.05$. Consequently, that shows a statistically significant difference between means of pupils' grades enrolled in the experimental group at the favor of the post application.
\end{abstract}

Keywords: Curricula - Kindergarten-Puppet Theater-Egypt's 2030 vision.

\section{Introduction}

The trend of the puppet theater in its various types with its beloved personalities for children at this critical stage in the life of the child and the theater in its effectiveness, as confirmed by many studies, was the means used to expose this group of children to the concepts and principles of the vision of their homeland in which they belong and live, but in a simple and exhilarating way that educates him and makes him happy. The field of child education and simplifying the concepts to be in the level of his awareness and understanding [1].influence of puppet theatre in simplifying concepts for the child has thus become a way of acquiring several behavior's such as the study of children (using Puppet Theater to acquire such positive and social behavior's in pre-school children), therefore it becomes clear how important Puppet Theater is and how successful it is in acquiring various values and beliefs in the simplest form in the kindergarten [2]. Some teachers are dependent on their particular case laws and the degree of understanding of the educational role of children's theatre, as well as the close relationship between the different styles of theatre [3].Egypt's 2030 vision is committed to shaping for vision in the country and its members' ongoing growth and advancement. Identify the core themes of this vision [4]. Among these are: a vibrant culture-a dynamic economy-an optimistic government. The emphasis of the country is on every citizen, including children from pre-school ages [5]. Given the significance of puppet theatre and the 
neglect of kindergartens and marginalization, despite the fact that it is an efficient way to mix education and entertainment together [6]. Many studies have shown that the puppet can infiltrate the entire curriculum so that the child can learn various concepts and subjects [7].it can be used along with the kindergarten Children to allow Egypt's 2030 vision to be seen [8] . The capacity of children to mimic the behavior of others is proof of the effect of learning on our children's development; Brian Way underlined the importance of using drama to instruct people, but in order to monitor all the principles and skills of the drama before using drama [9].

\section{Methodology}

The significance of the study is due to the identification of an significant period in the individual's life is the stage of kindergartens where character characteristics are formed influencing his future behavior. The practical implementation of the study was carried out in a kindergarten of the Fayoum Governorate Ministry of Education, Researcher's overview of the Egypt's 2030 vision basic concepts.

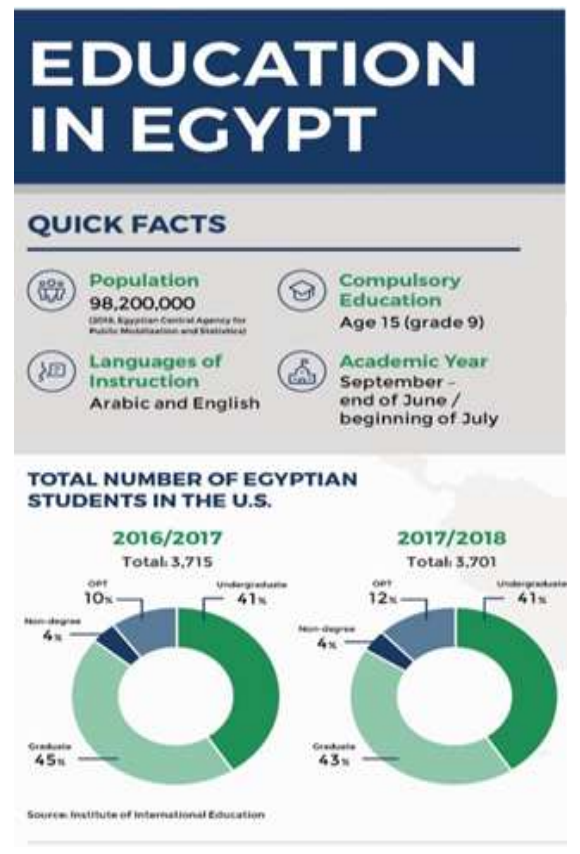

Figure (1) Facts about Education in Egypt https://wenr.wes.org/2019/02/education-in-egypt-2
In keeping with the Egypt's 2030 vision, the researcher Prepared (6) play that was in line with the objectives of promotion of citizenship as well as the creation of evaluation cards for theatre scenes. The research sample consisted of) 50(pupils in kindergarten in Fayoum Governorate. The researcher used the statistical program SPSS to perform the following transactions (T-test - Pearson coefficient to calculate the correlation coefficients).

\section{Result}

Study used the T-test to calculate mean related to the comparison of children's mean grades, before and after the experimental group, on the play evaluation card, to evaluate the performance of children from the experimental group on the play evaluation card. Theatre, before and after the submission. The following table includes a description of the T-test outcomes on the assessment card for children's grades.

Table (1) T-test findings for the discrepancy between children's mean grades in the experimental category in the plays assessment cards Pre and post application.

\begin{tabular}{|l|l|l|l|l|l|}
\hline Group & mean & $\begin{array}{l}\text { Standard } \\
\text { Deviation }\end{array}$ & DF & T & Sig \\
\hline Pre & 2.44 & 0.20 & 49 & 50.2 & Function \\
\hline Post & 8.44 & 0.41 & & 2 & \\
\hline
\end{tabular}

Table (2) T-test for Pre and post-application of the principles outlined in the evaluation card

\begin{tabular}{|l|l|l|l|l|l|l|l|}
\hline \multirow{2}{*}{ Play } & & No. & mean & S D & DF & T & sig \\
\hline \multirow{2}{*}{1} & Pre & 50 & 3.22 & 0.59 & 49 & 29.12 & Function \\
\cline { 2 - 5 } & Post & 50 & 8.56 & 1.12 & & & \\
\hline 2 & Pre & 50 & 4.18 & 0.85 & 49 & 28.34 & Function \\
\cline { 2 - 5 } & Post & 50 & 8.41 & 1.27 & & & \\
\hline 3 & Pre & 50 & 2.52 & 0.87 & 49 & 21.91 & Function \\
\cline { 2 - 5 } & Post & 50 & 8.79 & 1.19 & & & \\
\hline 4 & Pre & 50 & 2.8 & 0.86 & 49 & 24.57 & Function \\
\cline { 2 - 5 } & Post & 50 & 8.54 & 1.24 & & & \\
\hline
\end{tabular}

\section{Discussion}

The above results indicate the high level of children's answer to play evaluation cards due to:-

- Within the experimental kindergarten the lack of introducing these puppets and not 
teaching the teachers to use this type of puppets.

- The children and teachers enjoy the dramatic presentations during the show and are keen to see them, where it was first shown inside the experimental kindergarten.

- The teachers' keenness to watch the plays, particularly the (scarecrow-maskfinger-stick) plays, to learn how to implement and show.

\section{Conclusion}

In the light of the current results of the search, the following has been concluded:

1) The puppet theatre had an influence on children's understanding of the Egypt's 2030 vision.

2) The findings of the research as a whole are helpful in terms of the efficacy of theatre performances and their effects on the kindergarten boy.

3) This is demonstrated by the application of the post plays assessment cards and their understanding of the concepts provided to them after the presentation of theatrical performances.

\section{References}

[1] Mahmoud Al-Basyouni (1992): A proposed program for developing social skills for the concept of the role through creative dramatic activity (Shadow Fantasy Theater) for a pre-school child, an unpublished master's thesis, Faculty of Education, Minia University.

[2] Muhammad, Metwally (2017), Children's Theater and Drama, Its Applications for Normal Children and Special Needs, AlMutanabi Library, Kingdom of Saudi Arabia, 2nd Edition

[3] Awais, Massad (1988): A study on Child Theater in the integrated education of young people on child theater, Cairo, Egyptian General Book Authority.

[4] Raslan, Sawsan (2006): Sources of Political Education, State Information Service, Cairo, Edition 1
[5] Shaban, Wafa (2016). The effectiveness of using Puppet Theater in implementing a right curriculum. I play, learn and innovate on the development of some social and ethical concepts among kindergarten children. Master Thesis .

[6] Abdel Moneim, Zainab (2000): The Effectiveness of Using Child Theater Games as an Introduction to Social Learning in Light of Kindergarten Objectives, Master Thesis, unpublished, Girls' College, Ain Shams University.

[7] Abd al-Basit, The Spirituality of Muhammad (2015), the effective role that puppet theater offers to children, Journal of Childhood Studies, Journal of 18, No. 66

[8] Abdel Karim, Amal (2010). The use of puppet theater to teach pre-school children some positive social behaviors The Journal of Childhood Studies. The Journal 13 Issue 47.

[9] Mikhail, Emla (1996): Puppet theater as a method for providing children in Riyadh with some basic concepts. Jean Piaget: An experimental study, a doctoral thesis, unpublished, Institute of Higher Studies for Childhood, Ain Shams University

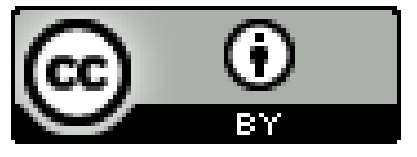

